\title{
I kroppens egne - indledning
}

\author{
af Jørn Hansen og Niels Kayser Nielsen
}

\section{Freden er sluttet -2 . verdenskrig er forbi!}

I sjælden grad har processen, der førte til fredsslutningen afsløret, at grænsedragningerne i Europa efter 1. og 2. verdenskrig ikke stemte overens med folkenes opfattelse af national identitet. Få steder i det $\varnothing$ vrige Europa er der som i Danmark harmoni mellem folk, nation og stat. Alligevel er nationalismebegrebet besværlig for mange danskere.

Alt for hurtigt bliver det til selvgodhed, angst for andres ekspansionstrang og kulturimperialisme, og alt for let bliver det ledsaget af fjendebilleder. Stærkere er nationalismen åbenbart ik$\mathrm{ke}$, end at den bestandig må stives af; enten det nu er russerne, tyskere, færinger eller tyrker som kan være behjælpelig med at opbygge identiteten. For den er det, hævdes det fra mange sider på tærsklen til det store europæiske unionsfællesskab, som er det prekære. Nationalfølelse borger for identitet, og identitet hævdes også at inkludere det at være noget særegent dansk. Hvordan det er med de dele er dog ikke så let at sige.

I hvert fald er det interessant at konstatere, at noget af det mest relevante, der er skrevet om det særegent danske og om det at være dansk i historien er Aarhus-historikeren Uffe Østergårds overvejelser om danskhed set i lyset af et komparativ studie i nationalstatsbegrebet. Først i lyset af noget Andet kommer vores særpræg til syne. Man kan jo ikke se sig selv i øjnene med egne øjne.

Skal man tale om identitet bør man med andre ord operere med to faktorer: dels vores egen identitetsopfattelse, dels andres oplevelse af os og vores identitet. Det er psykoanalytikeren Erik H. Erikson, som i sine studier i indiansk børneopdragelse har gjort opmærksom på dette elementære vilkår som modvægt til det endimensionale selvgode identitetsbegreb. Identitet er således altid dobbeltbaseret, knyttet til både nærvær og distance. Det er vel også derfor, at vi har lettere ved at se det danske efter at have været i udlandet. - Eller når vi befinder os ved $\mathrm{i}$ brudflader og ved grænser, som f.eks. på færgen mellem Helsingør og Helsingborg og ved danskhedens forposter hos Poetsch og Otto Duborg i Flensborg. Her mærker man den særlige danske folkelighed. Paderbornere, grøn Cecil, lilla Bols og perlevin, Mariannekarameller, en lidt sjusket påklædning og et lidt rundere kropssprog. Og pludselig slår det én, at Evelyn Waugh havde ret, da han kaldte danskerne for »the most exhilarating people in Europe«. Blot ærgerligt at man skal til til Stockholm eller Paris for at kunne se det. Til daglig er munterheden til at overse. Ikke fordi danskerne ikke er muntre og livsglade, men fordi der, med Ernst Blochs ord, aldrig er lys ved fyrtårnets fod.

Eller måske er det fordi, vi intellek- 
tuelle danskere ønsker at bære vores del af eurocentrismens åg. Hos Kipling var »the white mans burden « en opgave der skulle løses. I dag væmmes mange ved den eurocentriske løsningsmodel. Det 19. og 20. århundredes udbredelse af det europæiske system til det meste af verdenen har gjort etnologien til et problem. Dette har fået en del etnologiske forskere til at sætte sin egen eksistens på spil. Enzenberger kalder dem overløbere. Forskeren bliver så at sige til overløber. Han gør fælles sag med sine melanesier, nahuaer, malagassere ude i vildnisset. $\mathrm{He}$ goes native, var det udtryk, den engelske koloniherrer i sin tid brugte om et sådant form for identitetsskifte. Den nyankomne forsøgte at trænge ind $\mathrm{i}$ mentaliteten hos de folkeslag, han opholdt sig hos, ved selv at forvandle sig til melanesier, nahua, malagasser.

En række af disse »overløbere « har set menneskehedens hovedfjende i den civilisation - den eurocentriske - de kom fra. I de »vildes« liv har de set oprindeligheden, hvorpå fremtiden eller utopien skal bygges. Endnu har ingen dog formået at stoppe moderniseringsprocessen hos de folkeslag, der selv er uvidende om deres »eksotiske" levevis og i stedet $\mathrm{i}$ materiel forstand $\emptyset$ nsker bedre levevilkår. De vil have maskiner i stedet for plejle, biler i stedet for trækvogne, køleskabe, ferierejser, telefoner, treværelseslejligheder. Præcis som vi. Hvad det angår er den tredie verdens folk i dag mere eurocentriske end europæerne.

Man skal således tilbage til den europæiske velstand for at søge efter viljen til at bevare en mere autentisk og oprindelig identitet. Måske findes den på regionalt for ikke at sige lokalt plan. Tanken er forførende; det »indre mar- ked « taget $\mathrm{i}$ betragtning. Her bliver vi jo alligevel kun en egn. Men rigtig troværdig er den nu ikke. I det mindste ikke i første omgang.

I Henrik Ussings bog om »Minder fra det gamle Errits $\varnothing \ll$ (syd for Fredericia ud til Lillebælt), som de omliggende landsbyer før i tiden morede sig over på grund af de gamle sæder og skikke, kan man læse, at Errits $\emptyset$-boerne' på deres side pr. tradition har gjort sig til bedste over de endnu mere usamtidige Trelde-bønder (oppe ved sydsiden af Vejle Fjord). Høg over høg. Utålsomhed og latterliggørelse: der er de onde og de gode, og så dem fra Trelde - og de kan ikke kende forskel på en ged og kanin, sagde man før i tiden i Errits $\emptyset$. Men samtidig den gode - og selvsikkert fredelige - latter, der nok vedgår forskellighed og markerer grænser, men som også udligner latente konflikter, fordi man ved hvor man har hinanden og griner sig frem til sin egen identitet: Treldeboerne omtalte dem i Errits $\varnothing$ som erritsøerne.

I lidt større målestok genfindes ovenstående problemstilling i Vest-tyskernes identitetsskabende afgrænsning over for »die Ossies « med deres »Trabies«. 35 år har givet mulighed for nye identitetsskabende afgrænsninger; har skabt en mur, der ikke uden videre forsvinder med den håndgribelige murs fjernelse.

Sagt på en anden måde: om identitet kan man tilsyneladende kun tale alvorligt for sig selv, og det man siger, kan man ikke stole på. Men heldigvis ligger der en verden uden for sproget, eller måske snarere indeni sproget, så at sproget bliver om-tale, omkring en kerne, en kerne af kropslighed.

Heri ligger identiteten forankret (jvf. 1. afdeling om livshistorier og 
kropskultur i det lokale miljø) og kan i denne rodfæstethed brede sig ud i st $\varnothing r-$ re cirkler: den nationale kultur og den internationale, $i$ form af eksport af sport og kropskultur (jvf. 2. afdeling om idræt og nationalstatsbegrebet) og import tilbage igen af hidtil nye former for kropskultur, som kan bidrage til nye identitetsoplevelser (jvf. 3. afdeling) i form af kroppenes samtaler.

Det er denne relation mellem kropsbaseret og idrætsformet forankring og ekspansion, der er temaet i Idrætshistorisk Årbog 1990. Årbogens tema tager således fat på et emne, der har udgangspunkt i foreningens (Idrætshistorisk Forening Krop og Kultur) sidste to begreber. Det er en central tese, at kropskultur og idræt snarere end omtalende identitetsafstivninger er en mellemfolkelig kontaktformidler. Den prekære identitet kommer mere til orde i kroppens handlinger og udtryk end i munden. - På den anden side nærer ingen af de 12 bidrag, der som tidligere år udgøres både af essays og artikler, illusioner om, at kropskulturen og idrættens verden er konfliktfri og uden magtmarkeringer. „Der findes ikke nogen mere elementær form for magt end den, som kroppen selv udøver«, skriver Elias Canetti i sit filosofiske hovedværk om »Masse og Magt«. Men hvor paradoksalt det end lyder er kroppens magtudvørelse fredeligere end talens. I det mindste når den er formgivet, som tilfældet er i idrætten og sporten og i latterkulturen på Grønland, i Errits $\varnothing$ eller i Tyskland. Hvor talen hidser, dæmper kroppen. Heri består dens civilisatoriske kraft, selv i et kulturimperialistisk regi.

Denne civilisatoriske kraft er der så meget desto mere grund til at interessere sig for, som vi her i slutningen af det 20. århundrede står over for store trusler om etnisk uro og regionalistisk selvhævdelse i $\varnothing$ st og Vest for slet ikke at tale om den reelt eksisterende, men dårligt erkendte Nord-Syd-problematik. Meget af denne uro skyldes centralistiske samfundsformationers eliminering af identitetsoplevelser: jo mere disse nægter at godkende den lokale identitet, desto voldsommere bliver behovet for at hævde denne identitet. Og så er vi tilbage ved Erik H. Eriksons studier i indiansk socialisation: det barn, hvis særpræg og egenidentitet man viser tillid, bliver stærkt og tillidsfuldt med en markant identitets-fornemmelse og har ikke behov for at hævde sig. Omvendt forholder det sig, når identiteten ikke anerkendes.

Med kroppens basale rolle for oplevelse af selvet skulle det gerne være klart, at kropskulturen, også på regionalt plan, fortjener fuld opmærksomhed.

\section{Litteratur}

Canetti, Elias: »Masse und Macht«, (1960) Frankfurt à Main 1980.

Erikson, Erik H.: »Barnet og samfundet» (1968), Kbh. 1983.

Enzenberger, Hans Magnus: »Vanvittig normal« (1988), Kbh. 1990.

Ussing, Henrik: "Minder fra det gamle Erritsø«, Kbh. 1919.

Østergård, Uffe: »Hvad er det »danske« ved Danmark? « Tanker om den »danske vej« til kapitalismen, grundtvigianismen og »dansk « mentalitet. I »Kultur, mentalitet, ideologi«, Den Jyske Historiker nr. 29-30 1984. 
